Acta Universitatis Wratislaviensis No 3836

Anglica Wratislaviensia LVI, Wrocław 2018

DOI: 10.19195/0301-7966.56.4

\author{
Wojciech Drąg \\ ORCID: 0000-0002-9089-2465 \\ University of Wroclaw \\ wojciech.drag@uwr.edu.pl
}

\title{
The Curricular Canon of Twentieth- and Twenty-First Century British and Irish Literature at Polish Universities
}

\begin{abstract}
In 2007 Philip Tew and Mark Addis released Final Report: Survey on Teaching Contemporary British Fiction, whose aim was to establish the most popular authors and works as taught by academics at British universities. The purpose of this article is to present the results of a similar survey, which examines the reading lists of British and Irish literature courses offered in the English departments of chosen Polish universities (in Warsaw, Gdańsk, Toruń, Poznań, Łódź, Lublin, Wrocław, Opole and Kraków). A discussion of the results - most commonly taught writers and texts - is accompanied by an analysis (based on an online survey) of the lecturers' motivations behind including certain texts and omitting others. I will argue that whereas the teaching canon of modernist texts appears fixed (all the reading lists include works by James Joyce, Virginia Woolf, William Butler Yeats and T.S. Eliot), the canon of post-war and contemporary literature is yet to emerge. I shall also assert the appearance of the so called "canon lag" and review the selection criteria for the inclusion of canonical texts. The article concludes with a consideration of the texts that appear most likely to join the curricular canons at Polish universities in the near future. All the discussions are set in the context of critical contributions to the study of canonicity made by Harold Bloom, Nick Bentley, Dominic Head and others.
\end{abstract}

Keywords: canon, curriculum, survey courses, twentieth-century literature, British literature, Irish literature

The first aim of this study is to examine the make-up of the curricular canon of twentieth- and twenty-first century British and Irish literature as taught in the departments, institutes and faculties of English at Polish universities. The second aim is to establish the selection criteria for the syllabi of survey courses of the literature of the period in the said institutions. The context for those considerations has been set by the so called canon wars debate, which took place in the United States and Britain in the last two decades of the twentieth century. A brief summary of the legacy of this ideological confrontation will be followed by a discussion of 
the definitions and types of the canon as suggested by Harold Bloom, Nick Bentley and other academics. I shall then present the results of my study of the most commonly discussed authors and texts in the curricula of literature courses. That part will be followed by an analysis of a survey conducted among the professors of literature employed at Polish universities whose objective was to assess the popularity of general and specific criteria for including certain texts in the curricular canon and to predict which contemporary works are going to become canonical in the near future.

\section{The canon debates}

In the article "Aligning Curricular Canons with Academic Programs," Wendell V. Harris locates the source of the ideological conflict in the late 1970s, which saw the publication of two feminist studies calling for a revision of the dominance of male authors in the canon: Elaine Showalter's A Literature of Their Own (1977) and Sandra Gilbert and Susan Gubar's The Madwoman in the Attic (1979) (Harris 2000: 9). As Bentley argues in "Developing the Canon: Teaching Contemporary British Fiction," the ensuing debate was a battle between two camps: the conservatives and the revisionists. The former opted for the primacy of aesthetic over ideological criteria and supported an "organic evolution" of the canon (rather than a politically motivated revolution), whereas the latter were in favour of radically reforming the canon to make room for representatives of previously excluded groups, such as female writers and racial minorities (Bentley 2007: 29). Harold Bloom, although named by Bentley as the most prominent spokesman for the conservative camp, claims in The Western Canon to be unconcerned by the futile debate "between the right-wing defenders of the Canon, who wish to preserve it for its supposed (and nonexistent) moral values, and [...] the School of Resentment, who wish to overthrow the Canon in order to advance their supposed (and nonexistent) programs for social change" (Bloom 1994: 41).

In Britain the two poles were represented by Frank Kermode, who defended the epistemological value of a list of great works - safe from the tinkerings of the "cunning alliance of three forces... Feminism, Afro-Americanism and Deconstruction," and Terry Eagleton, who spoke against the very idea of a timeless canon, which cannot be exempt from ideological considerations (Bentley 2007: 28). In her article "Are the Canon Wars Over?," Mary Anne Frese Witt announces that the canon wars "have fizzled out to a kind of stalemate punctuated by periodic saber rattling (or cannon firing) and name calling form various factions" (Frese Witt 2000: 57). Although a clear winner has not been indicated, it seems that the reformist camp has managed to introduce some of the desired changes, especially in the emerging canon of contemporary literature. While following the "pluralistic impulse to empower suppressed voices" tends to be seen as a positive development, 
numerous critics have expressed their reservations about moulding the canon through the lens of "preconceived political determinants" (Head 2008: 5).

Bloom defines the contemporary canon, which he insists on spelling with a capital letter, as "a choice among texts struggling with one another for survival" (Bloom 1994: 20). He believes that the surviving "great works" are those that establish a dialogue with the "strong" authors from the past (Bloom 1994: 29). Among the possible agents of selection he lists "dominant social groups, institutions of education, traditions of criticism" and - the group which Bloom considers particularly important to canon formation - "late-coming authors who feel themselves chosen by particular ancestral figures" (Bloom 1994: 20). The aim of the canon, according to Bloom, is to offer the contemporary reader a rigid selection of the "great writers" at a time so "late in history" when the "Biblical three-score years and ten" do not allow the time to read any more than the greatest (Bloom 1994: 15). An important differentiation between the types of canons has been introduced by Harris, who complains about the term often being used with imprecision. He distinguishes between the official canon - institutionalized by educators and journalists, the curricular - taught in classrooms at all levels, and the critical canon - discussed in academic journals and book-length studies (Bloom 1994: 10). For the rest of my study I shall be concerned with the curricular canon at the university level.

\section{The curricular canon in Poland}

The first part of my study was concerned with collecting information about the texts included in the reading lists of survey courses of British and Irish literature after 1900 at Polish universities. For that purpose, I sent emails to colleagues from nine of the largest academic institutions offering such courses: seven Institutes of English (or of "English Studies") — in Warsaw, Kraków, Łódź, Wrocław, Gdańsk, Lublin and Opole; the Department of English in Torun; and the Faculty of English in Poznan. ${ }^{1}$ All of them offer survey courses - usually beginning in the first year of BA studies - but their length varies from two semesters (Warszawa and Łódź) to four semesters (Kraków, Wrocław, Lublin). Another important variable is the degree to which reading lists are subject to modification by individual teachers. In most places they are periodically negotiated by the staff, and changes are introduced when a consensus is reached.

Out of the nine institutions eight provided reading lists with specific texts and one containing only the names of the authors. The list below presents the authors

${ }^{1}$ Here I would like to extend my thanks to the following colleagues: Marek Błaszak, Mirosława Buchholtz, Grażyna Bystydzieńska, Anna Cichoń, Tomasz Fisiak, Elżbieta Foltyńska, Jarosław Hetman, Aleksandra Kędzierska, Bożena Kucała, Marta Mamet-Michałkiewicz, Agnieszka Setecka, Jean Ward and Tomasz Wiśniewski. 
from Britain, Ireland and the Commonwealth of Nations who wrote the most commonly discussed texts released after $1900^{2}$ :

Table 1: Twentieth- and twenty-first century authors most commonly included in the syllabi of English Literature

\begin{tabular}{|c|c|c|}
\hline Place & Author & Inclusions \\
\hline 1. & James Joyce & 9 \\
\hline 1. & Virginia Woolf & 9 \\
\hline 1. & W.B. Yeats & 9 \\
\hline 4. & W.H. Auden & 8 \\
\hline 4. & T.S. Eliot & 8 \\
\hline 6. & John Fowles & 7 \\
\hline 7. & Samuel Beckett & 6 \\
\hline 7. & Angela Carter & 6 \\
\hline 7. & William Golding & 6 \\
\hline 7. & Seamus Heaney & 6 \\
\hline 7. & Philip Larkin & 6 \\
\hline 7. & Harold Pinter & 6 \\
\hline 13. & D.H. Lawrence & 4 \\
\hline 13. & Ian McEwan & 4 \\
\hline 13. & John Osborne & 4 \\
\hline 13. & Salman Rushdie & 4 \\
\hline 17. & E.M. Forster & 3 \\
\hline 17. & Ted Hughes & 3 \\
\hline 17. & George Orwell & 3 \\
\hline 17. & Jean Rhys & 3 \\
\hline
\end{tabular}

The first observation to be made is the absolute dominance and the unanimous (or near-unanimous) choice of the canonical authors associated with modernism Yeats, Joyce, Woolf, Eliot and Auden. Among the other frequently taught authors associated with modernism are Beckett, Lawrence and Forster. Joseph Conrad would also join the group if it was not for the fact that Heart of Darkness was published in 1899, and therefore has not been taken into account. Despite the absence

${ }^{2}$ I have only taken into account authors and texts discussed during seminars rather than lectures. 
of Wyndham Lewis, Dorothy Richardson and several other influential authors, it needs to be noted that modernism occupies the central place in the syllabi of twentieth-century courses. The list of the most important modernist authors reflects the volume of critical material about them and their prominence in various companions to modernist literature. The editor of The Cambridge Companion to Modernism (2000) Michael Levenson notes that the list of go-to modernists has been fixed for a long time. With the exception of two American authors - H.D. and Langston Hughes, he argues, "it has been a while since there have been new candidates for inclusion in the modernist canon" (qtd. in Heller 1999: A23).

Despite the undisputed significance of modernism to British and Irish literature, it is possible to attribute the dominance of modernists among the most often taught authors to chronology. A different way of presenting the results would be to say that the most canonical figures of the twentieth century are those whose peak of creativity took place in the first decades of the century, which allowed enough time to pass before they achieved canonical status. ${ }^{3}$ The canon lag, as it might be called, varies considerably from author to author, but the results of this study suggest that it needs to be substantial. As many as four out of the five most popular writers were born in the nineteenth century - between 1865 and 1888. What is more, the top twelve does not include a single author who is still alive. Even though quite numerous contemporary authors feature in the syllabi of twentieth- and twenty-first century literature courses, there is only a minor overlap between them across different universities and hence their low scores in the above list.

Despite the prominence of Virginia Woolf and the inclusion of Angela Carter, Jean Rhys and Salman Rushdie, the canon remains largely male and white. With only three female writers and only two representatives of former colonies (without Chinua Achebe) among the twenty most popular authors, the list may be interpreted as an indication that the canon wars have not had a major influence on opening up the curricular canon at Polish universities. The list is also predominantly English, although as many as four Irish writers are included in the top twelve. It is surprising that some of the Nobel-Prize winning authors such as V.S. Naipaul, Nadine Gordimer (both absent from all reading lists), Doris Lessing and J.M. Coetzee (included in two syllabi) are so rarely considered. It may also be noted that authors primarily known as poets make up three of the five most commonly discussed writers. ${ }^{4}$ In the top twenty, however, it is the novelists who constitute the most numerous camp (of eleven), with only three playwrights.

As regards contemporary fiction writers, whose most important prose works have been released since the 1960s, one may observe a distinct overlap between

${ }^{3}$ On the other hand, such authors as Arnold Bennet, John Galsworthy, H.G. Wells and George Bernard Shaw, whose peak of creativity took place in the first decades of the twentieth century but whose work is rarely associated with modernism, do not fare well on the reading lists.

${ }^{4}$ As regards poetry, perhaps the most striking omission are the so called Great War Poets, such as Rupert Brooke, Wilfred Owen and Siegfried Sassoon, none of whom has been included in the top twenty. 
the above list and the list of most commonly taught authors provided in Philip Tew and Mark Addis's Final Report: Survey on Teaching Contemporary British Fiction (2007), which is based on Tew and Addis's study of the syllabi of contemporary British fiction courses in English departments of British Universities:

Table 2: Tew and Addis's list of the contemporary authors most commonly discussed during survey courses at Britain universities

\begin{tabular}{|l|l|c|}
\hline Place & \multicolumn{1}{|c|}{ Author } & Inclusions \\
\hline 1. & Angela Carter & 50 \\
\hline 2. & Salman Rushdie & 32 \\
\hline 3. & Jeanette Winterson & 21 \\
\hline 4. & Ian McEwan & 18 \\
\hline 5. & John Fowles & 15 \\
\hline
\end{tabular}

The top five of Tew and Addis's list contains as many as four authors included on the Polish list (Carter, Rushdie, McEwan and Fowles). The only writer absent is Winterson, whose works are discussed in two Polish institutions, as a result of which she occupies joint twenty-first position. The most noticeable difference between the two ranks is the overwhelming dominance of Carter over Fowles in the British survey (50 syllabi inclusions to 15) confronted with Fowles's narrow victory over Carter at Polish universities.

As mentioned earlier, most syllabi under consideration indicated specific works. A list of the most frequently included texts is given in the table below.

Table 3: Texts most often discussed during seminars on contemporary English Literature

\begin{tabular}{|l|l|l|c|c|}
\hline Place & \multicolumn{1}{|c|}{ Text } & \multicolumn{1}{|c|}{ Author } & Year & Inclusions \\
\hline 1. & $\begin{array}{l}\text { A Portrait of the Artist As a Young } \\
\text { Man }\end{array}$ & James Joyce & 1916 & 7 \\
\hline 2. & Mrs Dalloway & Virginia Woolf & 1925 & 6 \\
\hline 2. & Sailing to Byzantium & W.B. Yeats & 1928 & 6 \\
\hline 2. & The Waste Land & T.S. Eliot & 1922 & 6 \\
\hline 5. & Waiting for Godot & Samuel Beckett & 1953 & 5 \\
\hline 6. & The French Lieutenant's Woman & John Fowles & 1969 & 4 \\
\hline 6. & The Love Song of J. Alfred Prufrock & T.S. Eliot & 1915 & 4 \\
\hline 8. & Araby (Dubliners) & James Joyce & 1914 & 3 \\
\hline
\end{tabular}




\begin{tabular}{|c|l|l|c|c|}
\hline 8. & Look Back in Anger & John Osborne & 1956 & 3 \\
\hline 8. & Lord of the Flies & William Golding & 1954 & 3 \\
\hline 8. & Ulysses & James Joyce & 1922 & 3 \\
\hline 8. & The Tollund Man & Seamus Heaney & 1972 & 3 \\
\hline 13. & 1984 & George Orwell & 1949 & 2 \\
\hline 13. & Birthday Party & Harold Pinter & 1958 & 2 \\
\hline 13. & Caretaker & Harold Pinter & 1960 & 2 \\
\hline 13. & Hawk Roosting & Ted Hughes & 1960 & 2 \\
\hline 13. & $\begin{array}{l}\text { The Loneliness of the Long-Dis- } \\
\text { tance Runner }\end{array}$ & Alan Sillitoe & 1962 & 2 \\
\hline 13. & Midnight's Children & Salman Rushdie & 1981 & 2 \\
\hline 13. & My Son the Fanatic & Hanif Kureishi & 1994 & 2 \\
\hline 13. & The Passion & Jeanette Winterson & 1998 & 2 \\
\hline 13. & September 1, 1939 & W.H. Auden & 1939 & 2 \\
\hline 13. & Spain 1937 & W.H. Auden & 1937 & 2 \\
\hline 13. & Wide Sargasso Sea & Jean Rhys & 1966 & 2 \\
\hline
\end{tabular}

Since both the text table and the author table are based on the same results, all of the earlier made observations are applicable: particularly, the hegemony of modernist texts and the scarcity of works by female authors. What needs to be emphasised is the almost universal (in all the institutions that provided a list of titles except in Opole) inclusion of A Portrait of the Artist As a Young Man and the 75\% inclusion rate both for Mrs Dalloway and for the most widely discussed poems The Waste Land and Sailing to Byzantium. The most popular play is Waiting for Godot, which is part of more than $50 \%$ of the courses. In The Western Canon, Bloom notes that "in each era, some genres are regarded as more canonical than others" (Bloom 1994: 20-21). The above list, however, does not display a major imbalance and consists of nine novels (out of twenty-three works), seven poems, four plays and three short stories. Perhaps the most noticeable absence in the table above is that of any works by Carter and Larkin (who had six scores each in the author table), as well as of texts by McEwan (four) and Forster (three). The reason for their exclusion is the fact that each institution has selected a different work of theirs, which has resulted in a zero overlap.

Probably the most interesting observations can be reached by examining the publication dates of the most popular works. Although there is an almost exact balance between the works published in the first and in the second half of the twentieth century (twelve to eleven in favour of the latter), the list does not contain 
any texts written in the twenty-first century. The only post-2000 works which are discussed at Polish universities are Ian McEwan's Atonement (2001), Monica Ali's Brick Lane (2003) and Kazuo Ishiguro's Never Let Me Go (2005), each of which is included in only one reading list. That observation confirms the earlier mentioned notion of the canon lag, which prevents recent works or authors from being broadly accepted. An alternative explanation might be the limited availability of most recent texts; however, as will be argued later, that problem appears to have become a relatively minor concern since the arrival of the Internet.

It may also be noted that there are marked differences in the number of included texts from specific decades. The most productive decades are the 1920s, the 1950s and the 1960s (with four works in each). The highest concentration of canonical works occurs in 1914-1928 (seven texts) and 1952-1969 (eight), the former largely coinciding with high modernism and the latter — with the Angry Young Men movement and the onset of postmodernism. On the other hand, the least eventful decades are the 1940s (without a single work) and the 1980s (one). It may come as a surprise that from the twenty-year period between 1973 and 1993 only one text - Rushdie's Midnight's Children — appears on the list. After all, it is the 1980s that is often considered a watershed decade for the development of British literature - a time of its dynamic internationalisation and opening up to new voices. Peter Childs argues that the 1980s "has generally been seen as the foremost period for British fiction since the war" (Childs 2012: 11). Critics often indicate Rushdie's novel — and its Booker Prize triumph — alongside the announcement of the first Granta list of the Best Young British Novelists as the turning point for the British novel and the inauguration of the label of "contemporary British fiction." It is probably for that reason that Midnight's Children tops the list of most commonly discussed contemporary novels at British universities according to Tew and Addis's survey. In Poland, however, it is included in the survey courses of only two institutions under consideration, which still makes it the joint winner in the category of contemporary British novels provided that The French Lieutenant's Woman is not taken into equation.

\section{Selection criteria}

The second part of my study was based on a survey conducted via Google Forms in May 2017. It consisted of eliciting responses to questions about the general criteria adopted when choosing a text for inclusion in a survey course in literature and about the reasons why specific works have been included. The last part of the survey was a request to predict which works written since the 1990s are going to be accepted as canonical in the near future. Among the individual texts referred to in the survey were nine out of the twelve most popular works in the earlier table. The thirteen 
respondents were all professors specializing in the field of twentieth-century British and Irish literature affiliated to the nine earlier listed institutions. ${ }^{5}$

According to $77 \%$ of respondents, the most important criterion for selecting texts for the curricular canon is their "being representative of a given artistic movement (e.g., modernism or postmodernism) or of an important aspect of the literature of the time." From the eight remaining options only two were indicated as the most significant by a single respondent each: "the importance of the author (and this work being representative of their output)" and "the staff's research interests." The dominance of the first criterion is also clearly visible in the responses concerning the criteria for adopting specific texts, especially in the case of longer works, such as novels (A Portrait of the Artist As a Young Man, Mrs Dalloway, The French Lieutenant's Woman and Lord of the Flies, Waiting for Godot and The Waste Land). The text being representative of its movement (in most cases modernism) was indicated by $54-92 \%$ of respondents, ${ }^{6}$ with as many as twelve out of thirteen pointing to this criterion being central to the inclusion of Fowles's work, whose role in most syllabi appears to be that of the quintessential example of the postmodernist novel. In the case of shorter works, such as Araby, Sailing to Byzantium and The Tollund Man, that criterion is either equally significant as the importance of the author or declared less vital - as is the case with Yeats's poem, which according to over twice as many respondents is being studied because of the insight it offers into the poet's output rather than into modernism.

None of the remaining criteria has been indicated in the context of any text by more than $50 \%$ of those surveyed. "Influence on later works by other writers" was ticked by $0-46 \%$ of respondents. This criterion was particularly relevant to the inclusion of Waiting for Godot, The Waste Land and The French Lieutenant's Woman. "Offering insight into its time and being illustrative of the sociopolitical climate" was chosen by $0-38 \%$. Whereas that criterion seems inapplicable to all of the shorter works, it is fairly important to the acceptance of Mrs Dalloway, The Waste Land and Lord of the Flies. A possibly surprising observation is that the capacity of students for reading and understanding the assigned texts is not considered particularly important, with $0-38 \%$ of respondents highlighting this criterion. While no professor was of the opinion that Woolf's or Fowles's novels have been adopted with that consideration in mind, about a third of them saw it as relevant to the inclusion of Araby and Lord of the Flies. One respondent added a comment saying that longer works are occasionally replaced with shorter ones in order to meet students' capabilities. Despite the relatively low number of texts being selected because they might be palatable to students, two professors stated that this criterion is adopted these days more often than two decades ago.

${ }^{5}$ Here I would like to thank Marek Błaszak, Mirosława Buchholtz, Jerzy Jarniewicz, Anna Kędra-Kardela Bożena Kucała, David Malcolm, Agnieszka Setecka, Piotr Spyra, Krystyna Stamirowska and Jean Ward.

${ }^{6}$ In the section of the survey devoted to the criteria for specific works, respondents could tick multiple options. 
The least important criteria among those offered as options are the awarding of the Nobel Prize for literature to its author (slightly more significant in the case of Golding and Heaney than Beckett) and the availability of the text (only taken into account in the context of Eliot's poem). Availability was deemed by one professor as relevant "up to about 10 years ago" - now, when most canonical texts are available on the Internet, it has become "totally irrelevant." Several respondents suggested their own criteria for including specific works: the popularity of Golding's novel was attributed to its use of dystopia and its treatment of childhood as well as to it being a "canonical work of world literature." The centrality to world literature was also noted as significant in the case of The Waste Land and Waiting for Godot.

All respondents except one offered their predictions as to which texts written since the 1990s will be added to the reading lists of survey courses. The most commonly mentioned authors were the following:

Table 4: Authors expected to join the contemporary literature curricular canon

\begin{tabular}{|l|l|c|}
\hline Place & \multicolumn{1}{|c|}{ Author } & Inclusions \\
\hline 1. & Ian McEwan & 4 \\
\hline 1. & Zadie Smith & 4 \\
\hline 3. & A.S. Byatt & 2 \\
\hline 3. & Carol Ann Duffy & 2 \\
\hline 3. & Graham Swift & 2 \\
\hline 3. & Sarah Waters & 2 \\
\hline
\end{tabular}

A third of those surveyed pointed to Zadie Smith's White Teeth $(2000)^{7}$ as the likeliest candidate, whereas a quarter expected McEwan's Atonement (2001) to join the canon. ${ }^{8}$ The only other work to be mentioned by at least two respondents is A.S. Byatt's Possession (1990). Two professors each predict that some work by Carol Ann Duffy, Sarah Waters and Graham Swift is going to be included too. The most recent text appearing on the list of possible additions is David Szalay's collection of short stories All That Man Is (2016). It is interesting to note that even though there are only three female authors among the twenty most commonly discussed twentieth-century British and Irish writers in Poland, the solid majority (15 out of 25) of contemporary authors expected to join the canon are women.

7 Peter Childs also deems White Teeth "the most likely British novel of the new millennium to be studied at University" (Childs 2012: 19), whereas Leigh Wilson calls it the academic staff's favourite novel to teach as it enables them to make points about multiculturalism and national identity (Childs 2012: 20).

8 Atonement has already been included in a survey course in Wrocław and in an elective course called British Novel after the 1970s in Poznań. 
Alongside Smith, Byatt, Duffy and Waters, respondents have mentioned Beryl Bainbridge, Pat Barker, Penelope Fitzgerald, Tanika Gupta, Sarah Kane, Hilary Mantel, Rebecca McManus, J.K. Rowling, Arundhati Roy, Ali Smith and Jeanette Winterson. The group of canon hopefuls is also proportionately more ethnically diverse and contains several high-profile representatives of sexual minorities.

\section{Concluding remarks}

The expected make-up of the curricular canon of contemporary writing may be interpreted as a resounding victory of the "cunning alliance" - in Kermode's words - of feminists and multiculturalists. The canon wars, although waged far away, appear to have left a legacy traceable to the expectations of Polish academics as regards additions to survey course reading lists. That legacy, however, is barely noticeable in the current shape of the curricular canon, which - especially in the case of the first half of the twentieth century - is largely fossilised and contains the same works by modernist long-time usual suspects: predominantly white, male and upper-class. The greater variety of recent works and their frequent endorsement of ideological positions such as multiculturalism can be interpreted as indicating a shift from the more conservative - Bloomian - conception of the canon as motivated by purely aesthetic concerns to an idea which Bentley calls a "postmodern model of canon formation," which "rejects the idea of a single monolithic body of great works ... but is rather a series of partial, plural and distinctly multicultural canons that are responsive to the particular situation in which each separate institution operates" (32). Among the respondents were supporters of both conceptions: one professor stated that "canon is canon [and] should resist pressures of ideology and temporary fashion," whereas another noted that "reading lists are always arbitrary, provisional and incomplete and [teachers should] be ready to modify [them]." The followers of the latter idea of the canon predicted the inclusion of works of popular literature, children's literature and fiction-based computer games, which is a prospect that would probably make Bloom shudder.

\section{References}

Bentley, N. 2007. "Developing the Canon: Teaching Contemporary British Fiction.” In: Barfield S., A. Muller-Wood \& P. Tew (eds.). Teaching Contemporary British Fiction. Heidelberg: Universitätsverlag Winter. 27-45.

Bloom, H. 1994. The Western Canon: The Books and School of the Ages. New York: Harcourt.

${ }^{9}$ One respondent declared that the main change which has occurred in the selection criteria has been the rise to prominence of texts "representative for the thus-far marginalized voices." 
Childs, P. 2012. Contemporary Novelists: British Fiction since 1970. Basingstoke: Palgrave Macmillan.

Frese Witt, M.A. 2000. “Are the Canon Wars Over?.” The Comparatist 24. 57-63.

Harris, W.V. 2000. "Aligning Curricular Canons with Academic Programs." The Comparatist 24. 9-29.

Head, D. 2008. The State of the Novel: Britain and Beyond. Oxford: Oxford University Press.

Heller, S. 1999. "Beyond the Usual Suspects: Scholars Expand the Modernist Canon." The Chronicle of Higher Education 46:11. A23.

Kermode, F. 2003. "Canon and Period." In: Walder. D. (ed.). Literature in the Modern World. Oxford: Oxford University Press. 27-31.

Tew, P. \& M. Addis. 2007. "Final Report: Survey on Teaching Contemporary British Fiction.” http:// english.heacademy.ac.uk/wp-content/uploads/2016/01/contemp_brit_fiction.doc.

Wilson, L. 2007. "Teaching Contemporary British Fiction: Some Preliminary Considerations." In: Barfield S., A. Muller-Wood \& P. Tew (eds.). Teaching Contemporary British Fiction. Heidelberg: Universitätsverlag Winter. 15-26. 